\title{
4. PRINCIPLES OF ART FROM ANTIQUITY TO CONTEMPORARY PEDAGOGY IN THE CONTEXT OF METHODOLOGY OF ART EDUCATION
}

\author{
Arbuz-Spatari Olimpiada ${ }^{269}$
}

\begin{abstract}
The methodologies of Art Education is a system of educational documents principles, rules, methods, procedures, forms - designed determinative - reflective thinking from teleology, content, communication arts / cultural / scientific, reception and receiver topic communicating, and are subject oriented educated / creator student under the laws of education, communication and artistic principles.
\end{abstract}

Key words: art principles, methodology of art education

\section{Introduction}

In the context of determining the methodology of art education there were researched important aspects of art pedagogy significant to our research, from the educational value of art (I.Kant, N.Dunăre, V.Vasilescu) to artistic-aesthetic education principles (Aristotle, A .Gulîga, I.Kant, Plato, M.Florian, Schiller, Humboldt W.von, C.Radu, Ch.Morris, M. Heidegger, Vl.Pâslaru) and from these, to the characteristics of a creative person (I.Moraru, I .Bontaş, Gh.Popescu, V.Munteanu, M.Dincă) to those of reception (M.Bejat, Gh.Popescu, Al.Roșca, M.Dincă, D.Mureșan), of the specific methodologies to arts education (I.Cergit, S.Cristea, Vl.Pâslaru etc.). There are mainly investigated the creative process and the artistic creativity laws of development, methods and forms of organization of the training process for training / development of creativity, discovering creative potential of education.

\section{Discussions}

The issue of research. Because all human activity is caused by an issue, need, necessity, we defined the scientific problem as a necessity of establishing the benchmarks for theoretical and methodological development of the artistic creativity in art - pedagogy students in studying the textile art the artistic print.

Establishing the object framework of the issue. Following a constituent principle of art and artistic reception - recreating the message of thework by decoding the artistic form / artistic language elements - we have located the problem in our research, namely in the language of the plastic arts, thus meeting the requirement of conceptualizing the research: establishing the object framework of the problem or linking the object to a research problem.

This was followed by the action of establishing the principles of the art of "Methodology of Artistic-Plastic Education" course in the artistic education. As demonstrated in the previous chapter, the defining components of creativity - the artist's personality, creative artistic activity, the created product (= masterpiece) and receiving, all these are subject to specific principles of artistic knowledge.

\footnotetext{
${ }^{269}$ Associate Professor PhD.,"Ion Creangă” State Pedagogical University, Chişinău, Republic of Moldavia, email: olimpiada123@mail.ru
} 
The historic excursus and the systematization of the theoretical marks for the methodology of artistic development of the students suggested a system of ideas, concepts, principles and theories, which are to be based on the methodology of this paper, which we present in Figure 1.

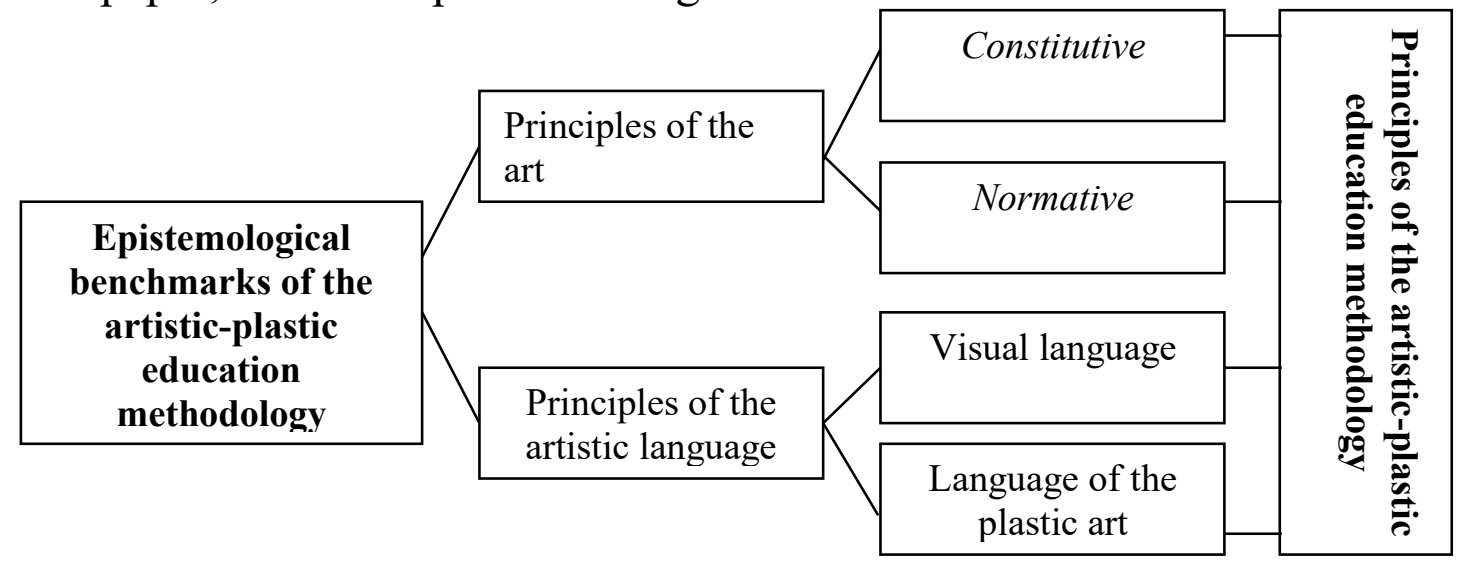

Figure 1. Structure of APEM's system of principles

An unique research of the artistic form / language was performed by Vl.Pâslaru (2001), which for the first time, systematized principles in art and literature in: constitutive principles, regulative principles and principles of poetic language (artistic). The Principles of the poetic / artistic language component is presented as it follows from different points of view:

- Origin from the form not from the concept (Aristotle, A. Gulîga);

- Harmony; Rhythm (Plato, Aristotle);

- Form as conceptual essence of an object; Trimorphosis of the poetic form (rhythm, harmony, intone); Metaphorical nature of poetic language; The clarity and the originality of poetic language; the Miraculous nature of poetic language (Aristotle);

- Universal communicability (Kant, M. Florian);

- The artistic form is significant (Schiller);

- Total symbolism of art; Conventionality of art; Art as a form of language; The specific structure of the artwork; The status of specific language, a means of interpersonal communication; The principle of equivalence expressive function of language to the degree of freedom in interpretation (C. Radu).

- The uniqueness of the artwork and its genurială integration; the Specifycation of the works on the subject or the subject's dominance; The principle of continue consecutiveness; The principle of unity; The principle of coherence; Unit shape (W. von Humboldt);

- Principle of iconicity (Ch. Morris, C. Radu) [Apud 11, p. 111-114].

V1.Pâslaru (2001) has structured the system of the constitutive principles, regulative and poetic language (= art) of art and literature, the productionreception; stated nature of the relationship subject-object-subject literary and artistic reception; has developed the original structure of the reading activity (= reception) [11]. Vl.Pâslaru has developed the theory of literary and artistic education (LAE), which includes as components a system of principles for LAE, 
structured in principles of art and literature and educational principles and those of the LAE - the principles to formulate objectives LAE, principles of selecting and structuring the content of LAE, the principles of selection and combination of LAE methodologies and a system of principles and evaluation criteria of students' literary development.

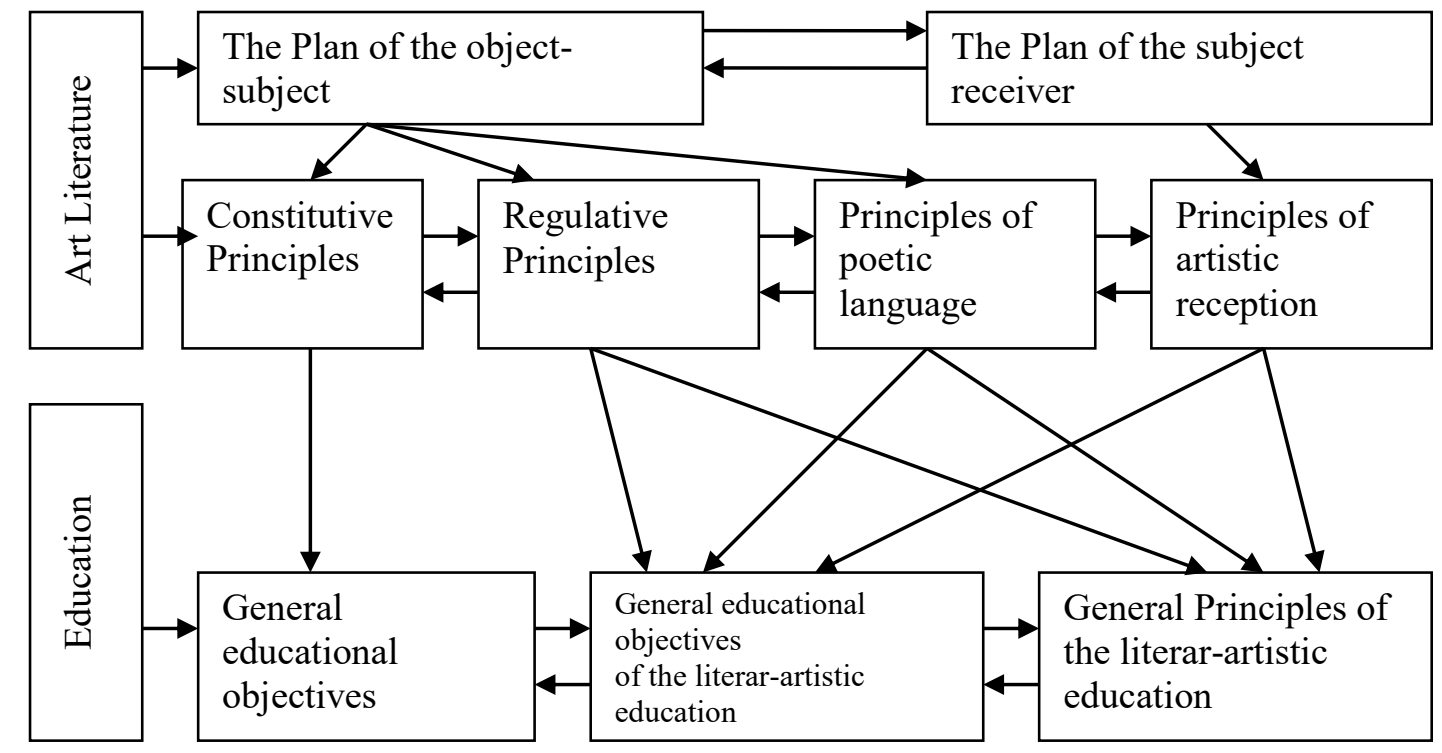

Figure 2. The artistic-aesthetic principles according to Vl.Pâslaru [11, p. 110]

Plato's philosophical system covers the whole world, including world of beauty and thought and therefore in his system we find principles specific for literature and arts: indoor-outdoor unit, the subject and object of knowledge and feeling, reason and enjoyment, to the whole and the part, contemplation and art making into truth; art as producing educational values; unity of physical, intellectual, spiritual and artistic education principles; connecting the content and educational objectives to the educated class; education based on values and for values; focusing on human and social ideals etc. [Apud Vl.Pâslaru, 11; Plato, $13,14]$.

Unity of interior and exterior in art relates directly to the unity of form and message, which, later was deduced the message reception principle through decipher the elements of artistic form. In the process of artistic creation this principle manifests opposite: creating the artistic message (= the work) by developing its artistic form [11].

Unity of subject-object of knowledge and feeling declares the human being as an affective being, affection is an organic part of knowledge, especially knowledge of art, whose specialty lies in knowledge processes and reception unit.

Unity of rationality and enjoyment (pleasure) discovers in the creativity and in the artwork the ability to make the rational of knowledge - pleasant, principle that appears mainly in art. Later, Aristotle will formulate the principle of catharsis. 
The unity of whole and part, Plato refers to the whole work, not only in artistic form.

The unity of art production and contemplation under the sign of truth is nothing else but the initial formula, Platonic, a generally recognized principle of unity reception and art creation. For Plato reception takes the form of contemplation, because in the Greek antiquity the dominant genres of art were theater (which included poetry), sculpture and architecture, and music, which calls for a reception-contemplation. The third part of the principle of truth, will be amply defined in the XXth century by M. Heidegger, demonstrating that there is apriori truth in art, but is re-created through the work of reception [3].

Art as producer of educational values, in Plato, is due to its ability to make things perfect, to ennoble the substance with spirit.

The unity of physical, intellectual, spiritual and artistic education principles, although it seems more a principle of general knowledge and arts education than one art, is part of Platon's philosophical system, which provides the foundation world unity. They world is unitary so the knowledge (= reception it) is unitary too.

Connecting the content and the educational objectives of the educated class is a general principle of knowledge and education, known today in the formula of principles of accessibility and adequacy of education to the specific education / receptor of the subject.

Platon's principle of education through values and for values does not require comments, but just the mention that its age and actuality, like all other principles of his philosophical system, testifies to the truth and its value in time and space.

The principle of centering the knowledge and education on human and social ideals also doesn't require comments, It continues till today to represent the unity of any educational discourse.

According to Aristotle, creativity is marked essentially by specific principles like mimesis (imitation), verisimilitude, demand and catharsis (purification).

The principle of mimesis clearly shows that art and its creation process is not a "reflection in artistic images of the objective reality," as stated by Marxist materialism but an imitation of it, art tends to create a specific reality, different from the physical one. [1, p.29-41].

The principle of veracity, in turn, indicates the character of mimicking similar and possible of artistic mimicry, which means that every element, every phenomenon of the artwork should have a similarity in physical and spiritual existence and / or be likely to occur coordinates of the two human existences [1, p.41-43].

The principle requirement is uniquely related to the spiritual needs of the people, but also indicates the fact that art and creation are phenomena that occur necessarily, that are causes of a universal system of preconditions: factors, facts, reasons, laws and laws etc. [1, p. 43-49].

The principle of catharsis, meaning the principle of purification through aesthetic pleasure is entirely spiritual home and is fully positive character [1, p.43-89]. Thus, unlike physical coordinates, the correction is applied 
purification or through coercion, rather than by explanation and persuasion, which are essentially all constraint (To convince. Formed of con- prefix + the vince Latin- Roman model...) [16], the catharsis causes a positive change in the receiver's art (in Christian dogma - salvation, perfection) exclusively spiritual pleasure.

Aristotle is important in the history of aesthetic due the fact that defined the work of art and creation as their default attitude - a defining principle in artisticaesthetic education and training of pedagogical art students [1, p.72-73].

According to I.Ianoţi, Kant commits a Copernican revolution by moving the perspective of the object worthy of being known to the capacity of knowledge itself $[4, p$ X]. Kant defines itself the aesthetic principles. The principles of nature (object of sciences) "does not say what happens", they function as our a priori knowledge. The principles of aesthetic expression of relations between nature and oversensitive (art), are determined by the faculty of judgment and belong therefore subject, not the object, as if nature. Principles determinative nature are addressed by the judgment, able to discover knowledge compliance with the object; aesthetic principles - the reflective faculty, which is subjective. Hence the beauty determinations, formulated by Kant according to four times of judgment rendered by I.Ianoţi as follows:

"According to the quality, the beautiful is disinterested (subject to satisfaction without any interest); according to the quantity, it is universally valid (which likes in an universally way, without concept); according to the relationship - is a subjective finality (purpose as an object, as we perceive without representation of purpose); appropriate manner - is namely necessary (what is known without concept as an object of a general satisfaction) "[4 p.XLI].

As it is at Plato, also at Aristotle, the ratio subject - object and perceptioncreation forms in Kant's opinion a dialectical unity and produces aesthetic pleasure. These ratios represent the 'object adequacy faculties of knowledge, which they put at stake reflective faculty of judgment "[5, p.85]. Such aesthetic judgment is a judgment on the finality of the object, which is not based on a concept of the object and provides no concept about it [Ibid.], so it's a subjective judgment, characteristic to art.

According to J.Kooper, " aesthetic pleasure transcends the domain of determinative thinking and with it also, both scientific thinking and empirical individual's self in the world" [8, p.40]. "Aesthetic pleasure is related to a formal experience of the reality of the world that includes the productive imagination in its autonomy. The reflective judgment, which we know through aesthetic pleasure, we do experience of form of the objects, that as a form, is beyond the distinction between matter and form of own determinative thinking "[Ibid.].

So, the subject-object relationship in the arts occurs in reflective thinking, where is regulated by the one law: unity of intellect and imagination, says Kant [Ibid., P.85-86]. The principle of imagination by Kant, explains Vl.Pâslaru, is freedom; intellectual principle - determinism [10, p. 72]. "Only the intellect gives law," writes Kant, imagination is free [5, p.134]. In art, according to Kant, 
there is "a subjective accordance between imagination and intellect" [Ibid.] in which the subject does not look like the object (as in science), but in the way it should (can) be [11, p. 72].

Since Kant, says I.Petrovici, the beautiful achieves self worth having as its source a distinctive quality; it is no longer burdened by the knowledge of the determinative principles [12]. Commenting upon Kant, I.Petrovici shows that the beautiful expresses / discovers / creates a truly universal value - artistic truth, as opposed to scientific truth which is determined by objective; aesthetic emotion comes from beautiful; "It arises when there is a perfect harmony between our artistic imagination and the patterns of our intelligence" [Ibid., P.256].

The illustrious scientist and culture man, German philosopher W. Von Humboldt, in addition to many other developments of ancient classical aesthetics, completes the reception principle with a thesis on imagining the imaginary [11, p.76], which defines reception as part of creativity, as imaginary activity of a product of the imagination - a work of art. Imagining the imaginary is the condition for freedom and creativity in art.

A particularly valuable epistemic beginning to our research, creates C. Radu by systematizing the study of art principles:

- sustainability: art is perennial;

- graduality: the creation and reception occur gradually from the artistic extraesthetic;

- utilitarianism: some genres of art are utility by destination other takes this capability to the development of mechanisms of perception of works of art;

- relative autonomy of art: art exists in and for itself; it doesn't have a defining extraesthetic motivation to condition it of other things [15, p. 97];

- social validation of artistic values: although created and perceived strictly individually, the social art require validation by virtue that man is a social being; - considering art as a form of language: any work of art is a form of language, by which he communicates artistic and aesthetic;

- methodological, according to which "more complex forms of development of the field give the key to understanding existent simplest forms, not vice versa ..." [Ibid., P. 101]); or the work of art, especially fine art is perceived as a whole, then it deciphered and thorough in its elemenele;

- iconicity: the work of art is always a figurative image, not a reflective;

- double determinations of the artistic act: the action of the author, and receiver;

- consistencyof innovation and tradition: innovation is based on tradition and values it [Ibid., P. 143];

- enhancing the artistic text by the subject - reader: receiver assigns to artistic text / artwork a value called reader's / receiver's value, added value [P.Cornea, 2, Vl.Pâslaru, 11], represented by his life, aesthetic and literary experiences [HRJauss, 7];

- receiver's priority, supported by J.Mukařovský [8]: the receiver, according to J. Mukařovský, is as important as the author, perhaps even more important, which basically corresponds to another; 
- principle of adequacy "of creation to taste, preferences and expectations of the public" [15, p. 199] - particularly important in artistic-aesthetic education in general and training in the field in particular;

- principle of equivalence of the expressive function of language with the degree of freedom in interpretation [15, p. 165-166], which states that the receiver's degree of freedom in interpreting art is equivalent to the expressive function of poetic language value ( $=$ art) of the work: a language causes a rich expressive interpretation and vice versa;

- freedom as indispensable feature of any aesthetic reception [Ibid., P. 166];

- multifuntional art [Ibid., P. 263-264]: art and creativity performed several functions (see above);

- Total symbolism of art: no work of art can not be as such if it would work with already known and new symbols created;

- accessibility of art [15, p. 280]: art is by definition accessible to any individual, has guidance for individual training at a level determined by its artistic- aesthetic formation.

Immanuel Kant. His work is of a particular value in education sciences because although Plato and Aristotle formulated educational principles, namely Kant is the first author of the modern era who clearly need decreed founding principles of education: "Education and training must not either purely mechanical, but it should be based on principles "[5, p.20], but the principles must necessarily be positive orientation: it is necessary" to establish good principles everywhere and we make them to be understood and admitted by children "[5, p.69]. But mostly, Kant is contemporary due to the fact tht its philosophical system is based on the principle of human freedom - the principle that, says Vl.Pâslaru, governs today's democratic society, represents the ideal of contemporary human [11].

Vl.Pâslaru explanations on Kant's concept show that knowing subject in the beauty domain becomes the exponent of his own freedom, this being given by the reflective judgment inconsistent to the determinative thinking, and that determination is the only unit intellect and imagination; artistic form is defining in decoding the essence the by engaging the intellect in object perception; aesthetic thinking is thinking of forms which reveals the essences of human freedom; art (poetry), by its nature, possesses immanent educational values, the ability to contemplate, reflect and appreciate the world we create is the autogenerated freedom supersensibly by reference to nature (the objective). [Ibid., P. 75]

Kant's aesthetic concept is defining the establishment of an epistemology of artistic-plastic education, giving an aesthetic-philosophical interpretation unsurpassed to this day on the primary issues of artistic beauty, the subjectobject ratio in the arts, freedom in art, artistic form etc. According to the same author, "Kant's aesthetics incorporates the fundamental constitutive and regulative principles, thus giving philosophy a normative value (positive) for the aesthetic education sciences" [11]. 
Significant for our research are the definitions of specific methodologies determined MEAP - Methodologies EAP is a system of educational documents principles, rules, methods, processes, forms - designed by determinativereflective thinking from teleology, content, communication arts / cultural / the scientific, reception, receiver and subject communicant, and are subject oriented educated / student reader under the laws of education, communication and artistic principles, methodologies and system-specific training / development in the years of schooling artistic creator.

Table 1 represents the principles of art as a system of ideas, concepts of reference authors from antiquity to contemporary pedagogy

\section{Principles of art from antiquity to contemporary pedagogy}

\begin{tabular}{|c|c|}
\hline Author & Principles and developed/ defined conceptual value \\
\hline Platon & $\begin{array}{l}\text { Inner - outer art units, subject-object art knowledge and feeling in art unit; } \\
\text { rational and enjoyment; the whole and the part; contemplation and art } \\
\text { making into truth; Default educational value of art (art as producing } \\
\text { educational values); unit physical education principles, intellectual, spiritual } \\
\text { and artistic; connecting content and educational objectives to the category of } \\
\text { those educated; education through and for values; art centering on human } \\
\text { and social ideals. }\end{array}$ \\
\hline Aristotel & $\begin{array}{l}\text { Mimesis (imitation) in art: verisimilitude; required; catharsis (purification } \\
\text { through art). }\end{array}$ \\
\hline Im.Kant & $\begin{array}{l}\text { The concept of nature and the concept of freedom; autonomous nature of } \\
\text { beauty and artistic knowledge; artistic knowledge as capacity knowledge; } \\
\text { - Determinations of beauty: selfless, universally valid, subjective finality, } \\
\text { necessary character; } \\
\text { - Dialectical unity of subject-object; Unity of imagination and intellect; } \\
\text { - The principle of imagination as freedom. }\end{array}$ \\
\hline $\begin{array}{l}\text { W. von } \\
\text { Humboldt }\end{array}$ & Imagining imaginary thesis \\
\hline Hegel & Identifying creative aesthetic activity as a path to freedom \\
\hline Şt.Lupa & $\begin{array}{l}\text { - The dynamic nature of artistic truth: truth in art becomes; } \\
\text {-Unity / diversity / complementarity of the subject and object: the picture is } \\
\text { simultaneously subject and object; } \\
\text { - The origin of freedom of artistic image and how the subject's intentionality } \\
\text { receiver, the receiver influencing factors; } \\
\text { - The ability of the artistic image of being simultaneously real and unreal; } \\
\text { - The dynamic, mobile and pluralist nature of the artistic image; } \\
\text { - Image as inner and acknowledged reality } \\
\text { - Creative imagination as a specific phenomenon psyche; } \\
\text { - Art as knowledge process knowledge, consciousness of consciousness; } \\
\text { - Fusion of subject and object art; } \\
\text { - Ability to offer creative imagination inner-outer freedom; } \\
\text { - Self sufficiency universes created by imagination - subjective and } \\
\text { objective, real and fantastic, true and false, etc .; } \\
\text { - The truth of creative imagination: here everything is true, because } \\
\text { everything is possible; and any possibility is a real one; } \\
\text { - The reversibile nature of temporality in art and playful nature of space; } \\
\text { - Art as a spiritual product that interaction of biological universes, physically }\end{array}$ \\
\hline
\end{tabular}




\begin{tabular}{|l|l|}
\hline & $\begin{array}{l}\text { and psychologically - art as a transfiguration of the real world; } \\
\text { - Conceptual value through excellence in art activity; } \\
\text { - The imminent emotion in art: art can not be without emotion; Condition is } \\
\text { a fact of being, so art is essential for the human being. }\end{array}$ \\
\hline M.Heidegger & $\begin{array}{l}\text { - the opera - artist unity: origins and interconditioning; occurrence of truth in } \\
\text { the work of art; } \\
\text { - art receiver as keeper of the artwork; receiver as the second creator of the } \\
\text { work }\end{array}$ \\
\hline I.Gagim & $\begin{array}{l}\text { Defining the type of music knowledge, musical thinking, feeling of the } \\
\text { music, state of singing }\end{array}$ \\
\hline Vl.Pâslaru & $\begin{array}{l}\text { - Structuring the system of constitutive, normativ and poetic language (= art) } \\
\text { principles of art and literature, the production-reception; } \\
\text { - Specifying the nature of the subject-object-subject ratio in the literary and } \\
\text { artistic reception; } \\
\text { - Developing of an original structure of the reading (= reception) activity } \\
\text { - Systematization of the principles of poetic language }\end{array}$ \\
\hline
\end{tabular}

\section{Conclusions}

An inventory of the definitions given to education principles always remains open because the principles are still being discussed. But establishing guidelines in defining principles of education is possible thanks to the convergence point for most definitions:

- interaction between determinative and the reflexive thinking, giving priority to reflective thinking and subjective delimitation of objective necessity;

- explanatory value-projective education principles;

- universal character education principles, manifest in their ability to regulate all areas of education (teleological, technological, content, epistemological);

- classification of education principles in terms of their scope of knowledge that are deducted and scope of application are proposed..

The researches that were analyzed, systematized in the present study confirms the interaction of creative teaching process as one of the main regularities of aesthetic artistic activity in education Artistic artistic education. EAP methodologies are specific, they are conforming to the laws and principles of art - reception and artistic creation.

\section{References}

1. Aristotel. (2000). Poetica. Bucureşti: Humanitas

2. Cornea, P. (1998). Introduction to the theory of reading. Iaşi: Polirom

3. Heidegger, M. (1982). The origin of the artwork. București: Univers

4. Ianoţi, I. (1981). Foreword. In I. Kand about beauty and good. Vol. I. Bucureşti: Minerva, p. V-LIII

5. Kant, I. (1992). Treaty of pedagogy. Religion in the limits of reason. Iaşi: Aurora SRL

6. Kant, I. (1981). Critique of Judgement. Bucureşti: Scientific and Encyclopedic Publishing 
7. Jauss, H. R. (1983). Aesthetic Experience and Literary Hermeneutics. Bucureşti: Univers

8. Kooper, J. (1981). Forms of understanding beauty in Kant. In: I. Kant. Critique of Judgement. București: Scientific and Encyclopedic Publishing 9. Mukařovský, J. (1974). Aesthetic studies. Bucureşti: Univers 10.Pâslaru, Vl. (coord.), Papuc L., Negură I. ş.a. (2005). Construction and curriculum development. Part II. Methodological framework. Chişinău: UPS Ion Creangă

11.Pâslaru, Vl. (2001). Introduction to the theory of literary and artistic education. Chişinău: Museum

12.Petrovici, I. (1993). Twelve university lectures on Kant I.. Iaşi: Aurora

13.Platon. (1993). Phaidros. Bucureşti: Humanitas

14.Platon. (1995). The Banquet. Bucureşti: Humanitas

15.Radu C. (1989). Arts and Convention. Bucureşti: Scientific and Encyclopedic Publishing

16.Roşca, A. (1981). General and specific creativity. Bucureşti: Romanian Academy Press 